\title{
PENGETAHUAN IBU TENTANG ASI EKSKLUSIF DITINJAU DARI PERSPEKTIF KESEHATAN DAN ISLAM
}

\section{Mother Knowledge About Exclusive Breast Feeding Assions Reviewed From Health And Islam Perspective}

\author{
Daryanto1, Titik Anggraeni2 \\ STIKES Mamba'ul 'Ulum Surakarta \\ (daryanto.mpi@gmail.com)
}

\begin{abstract}
ABSTRAK
Latar Belakang : ASI (Air Susu Ibu) adalah makanan terbaik bagi bayi karena mengandung berbagai zat gizi dan antibodi yang baik untuk pertumbuhan dan perkembangan.ASI eksklusif adalah bayi hanya diberi ASI tanpa tambahan cairan lain.Pemberian ASI eksklusif ini ibu harus menyusui bayi secara murni dalam jangka waktu minimal bayi berumur 0 sampai 6 bulan.

Metode : Penelitian ini merupakan jenis penelitian deskriptif dengan pendekatan cross sectional.Populasi pada penelitian ini adalah warga masyarakat Desa Bakulan, Cepogo, Boyolali pada bulan September 2017 - Februari2018. Teknik pengambilan sampel menggunakan teknik purposif sampling. Penentuan jumlah sampel menggunakan quota sampling berjumlah 200 responden. Variabel dalam penelitian ini adalah variabel tunggal, yaitu pengetahuan ibu tentang ASI Eksklusif dilihat dari perspektif kesehatan dan Islam. Alat ukur yang digunakan adalah kuesioner. Analisis data yang digunakan adalah analisis univariat berupa distribusi frekuensi responden berdasar pengetahuan dan pemberian ASI eksklusif sesuai dengan kategori.

Hasil : 72,5\% Ibu warga desa Bakulan, Cepogo, Boyolali memiliki pengetahuan tentang ASI eksklusif dengan kategori yang baik. 100\% responden memberikan ASI untuk bayinya, dimana 66,5\%(133 responden) memberikan ASI ekslusif selama 6 bulan.
\end{abstract}

Kata Kunci : Pengetahuan, ASI eksklusif, Kesehatan, Islam

\section{ABSTRACT}

Background : Breast feeding is the best food for babies because it contains various nutrients and antibodies that are good for growth and development. Exclusive breastfeeding is a baby given only breast milk without any additional fluids. This exclusive breastfeeding mother should breast-feed the baby purely within the minimum period of infants aged 0 to 6 months.

Method : This research is a descriptive research with cross sectional approach. Population in this research is citizen of Bakulan Village, Cepogo, Boyolali on September 2017 - February 2018. Sampling technique using purposive sampling technique. Determination of the number of samples using quota sampling amounted to 200 respondents. The variable in this research is single variable, that is mother's knowledge about Exclusive ASI seen from health and Islam perspective. The measuring tool that used was questionnaire. Data analysis used is univariate analysis in the form 
of frequency distribution of respondents based on knowledge and exclusive breastfeeding according to category.

Result : 72.5\% Mothers of Bakulan villagers, Cepogo, Boyolali are knowledgeable about exclusive breastfeeding with good category. 100\% of respondents gave breast feeding to their babies, of whom 66.5\% (133 respondents) exclusively breastfed for 6 months.

Keyword: knowledge, exclusive breastfeeding, health, Islam

\section{PENDAHULUAN}

ASI (Air Susu Ibu) adalah makanan terbaik bagi bayi karena mengandung berbagai zat gizi dan antibodi yang baik untuk pertumbuhan dan perkembangan. Bayi yang mendapatkan ASI secara eksklusif terbukti lebih cerdas dan tidak mudah terserang penyakit. ASI eksklusif adalah bayi hanya diberi ASI tanpa tambahan cairan lain, seperti susu formula, jeruk, madu, air teh, air putih, dan tanpa pemberian makanan tambahan lain, seperti pisang, bubur, atau nasi tim. Pemberian ASI eksklusif dianjurkan untuk jangka waktu hingga waktu sampai 6 bulan ( Danuatmaja, 2007).

Pemberian ASI eksklusif, ibu harus menyusui bayi secara murni dalam jangka waktu minimal bayi berumur 0 sampai 6 bulan, karena ASI itu sendiri merupakan nutrisi yang berkualitas, bisa meningkatkan daya tahan tubuh, meningkatkan kecerdasan dan menjalin kasih sayang antara ibu dan bayi (Dwiharso, 2011).

$80 \%$ perkembangan otak anak dimulai sejak dalam kandungan sampai usia 3 tahun yang dikenal dengan periode emas, oleh karena itu diperlukan pemberian ASI Eksklusif selama 6 bulan dan dapat diteruskan sampai anak berusia 2 tahun. Hal tersebut dikarenakan ASI mengandung protein, karbohidrat, lemak dan mineral yang dibutuhkan bayi dalam jumlah yang seimbang (Depkes RI, 2011). Pertumbuhan dan perkembangan bayisebagian besar ditentukan oleh jumlah ASI yang diperoleh termasuk energi dan zat gizi lainnya yang terkandung di dalam ASI tersebut. ASI tanpa bahan makanan lain dapat mencukupi kebutuhan pertumbuhan sampai usia sekitar empat bulan (Depkes RI, 2009).

Memberikan ASI dan ASI eksklusif didukung oleh berbagai pihak dan rujukan ilmu yang berhubungan dengan ASI. Sebagai umat muslim, memberikan ASI mendapat acuan berdasarkan Al-Quran surah Al-Baqarah ayat 233 "Para ibu hendaklah menyusui anak-anaknya selama dua tahun penuh, yaitu bagi yang ingin menyempurnakan penyusuan. Dan kewajiban ayah memberi makan dan pakaian kepada para ibu dengan cara yang makruf".

Anggota keluarga yang berperan dalam memberikan ASI dan ASI eksklusif adalah ibu. Pengetahuan yang cukup akan mendorong ibu untuk memberikan ASI dan ASI eksklusif bagi bayinya.Tujuan yang ingin dicapai dalam penelitian ini adalah untuk mengetahui gambaram pengetahuan ibu tentang ASI eksklusif ditinjau dari perspektif kesehatan dan Islam. 


\section{METODE PENELITIAN}

Penelitian ini merupakan jenis penelitian deskriptif dengan pendekatan cross sectional. Penelitian deskriptif adalah penelitian yang menggambarkan apa adanya tentang suatu variabel, gejala atau keadaannya. Dengan menggunakan pendekatan Cross Sectional, artinya tiap subyek penelitian hanya diobservasi sekali saja dan pengukuran dilakukan terhadap status karakter atau variabel subyek pada saat pemeriksaan/penelitian(Nursalam, 2011). Penelitian dilakukan di desa Bakulan, Cepogo, Boyolali, pada bulan September 2017 - Januari 2018.

Populasi pada penelitian ini adalah warga masyarakat Desa Bakulan, Cepogo, Boyolali.Teknik pengambilan sampel yang dilakukan dengan teknik purposif sampling yaitu pengambilan sampel berdasarkan pertimbangan tertentu dari meneliti untuk mencapai tujuan penelitian(Nursalam, 2011). Penentuan jumlah sampel dalam penelitian ini adalah quota sampling berjumlah 200 responden.

Variabel dalam penelitian ini adalah variabel tunggal, yaitu pengetahuan ibu tentang ASI Eksklusif dilihat dari perspektif kesehatan dan Islam.Alat ukur yang digunakan dalam penelitian ini adalah kuesioner.

Adapun analisis data yang digunakan adalah analisis univariat untuk mengetahui distribusi frekuensi responden berdasar pengetahuan dan pemberian ASI eksklusif sesuai dengan kategori.

\section{HASIL DAN PEMBAHASAN}

Tabel 1. Distribusi Frekuensi Pengetahuan Ibu tentang ASI Eksklusif di desa Bakulan, Cepogo, Boyolali

\begin{tabular}{|c|c|c|c|}
\hline No & Pengetahuan Ibu & Jumlah & Persentase \\
\hline 1 & Baik & 145 & 72,5 \\
\hline 2 & Sedang & 44 & 22,0 \\
\hline 3 & Kurang & 11 & 5,5 \\
\hline Tota & & 200 & 100,0 \\
\hline
\end{tabular}

Tabel 2. Pemberian ASI eksklusif bagi bayi dan balita di desa Bakulan, Cepogo, Boyolali

\begin{tabular}{llcc}
\hline No & Pemberian ASI ekslusif & Jumlah & Persentase \\
\hline 1 & Enam bulan & 133 & 66,5 \\
2 & Empat bulan & 35 & 17,5 \\
3 & Tidak diberikan ASI Ekslusif & 32 & 16,0 \\
\hline Total & & 200 & 100,0 \\
\hline
\end{tabular}

Sumber: data Primer, diolah 
Avicenna Journal of Health Research. Vol 1 No 1. Maret 2018 (22-28)

Tabel 3. Tabulasi silang pengetahuan Ibu tentang ASI Ekslusif dan Pemberiannya pada Bayi di desa Bakulan, Cepogo, Boyolali

\begin{tabular}{llcccc}
\hline \multirow{2}{*}{ No } & Pengetahuan & \multicolumn{2}{l}{ Pemberian ASI Eksklusif } & Total \\
\cline { 3 - 5 } & \begin{tabular}{l} 
Ibu tentang ASI \\
\cline { 3 - 5 }
\end{tabular} & Eksklusif & 97 & 4 bulan & $\begin{array}{c}\text { Tidak } \\
\text { diberikan }\end{array}$ \\
\hline 1 & Baik & 30 & 10 & 27 & 145 \\
2 & Sedang & 6 & 4 & 4 & 44 \\
3 & Kurang & 133 & 35 & 32 & 200 \\
\hline
\end{tabular}

Sumber: data Primer, diolah

Tabel 3. menunjukan bahwa ibu dengan kategori pengetahuan ASI eksklusif kurang, telah memberikan ASI eksklusif bagi anak sejumlah 6 responden, yang merupakan 54,5\% dari 11 ibu yang termasuk dalam kategori pengetahuan yang kurang tentang ASI eksklusif.

Pengetahuan merupakan hasil tahu, yang terjadi setelah seseorang melakukan penginderaan terhadap suatu obyek tertentu melalui panca indra manusia (Notoatmodjo, 2005).

Danuatmaja (2007: 37) menyatakan bahwa ASI eksklusif adalah bayi hanya diberi ASI tanpa tambahan cairan lain, seperti susu formula, jeruk, madu, air teh, air putih, dan tanpa pemberian makanan tambahan lain, seperti pisang, bubur, atau nasi tim. Pemberian ASI eksklusif dianjurkan untuk jangka waktu hingga waktu sampai 6 bulan.

Pemberian ASI secara eksklusif adalah bayi hanya diberi ASI saja, tanpa tambahan cairan lain seperti susu formula, air jeruk, air teh, airputih. Pada pemberian ASI eksklusif pada bayi juga tidak diberikan makanan tambahan seperti pisang, papaya, bubur susu, biskuit, bubur nasi, tim, dan sebagainya (Roesli, 2009).

Tabel 1. menunjukkan 145 responden(72,5\%) memiliki tingkat pengetahuan tentang ASI Eksklusif yang baik, 44 responden(22\%) cukup dan 11 responden(5,5\%) kurang. Hasil tersebut menunjukkan bahwa 72,5\% responden mengetahui tentang manfaat ASI eksklusif bagi ibu dan bayi, tehnik dan waktu pemberian, kewajiban dan tanggung jawab orang tua, terutama berhubungan dengan ASI eksklusif.

Tabel 2. menunjukan 133 responden(66,5\%) memberikan ASI eksklusif selama 6 bulan, 35 responden(17,5\%) selama 4 bulan dan 32 responden(16\%) memberikan ASI kombinasi dengan susu formula.

Tabel 4.3. menunjukan ibu dengan kategori pengetahuan yang baik tentang ASI eksklusif dan memberikan untuk bayinya berjumlah 97 responden, 66,9\% dari $145 \mathrm{ibu}$ dengan kategori pengetahuan baik dan 6 responden, 54,5\% dari 11 ibu dengan kategori pengetahuan kurang.

Hasil penelitian menunjukan bahwa ibu sebagian besar ibu telah memberikan ASI eksklusif bagi anaknya selama 6 bulan dan 4 bulan. Hanya 
$16 \%$ ibu yang memberikan kombinasi ASI dan susu formula. Ditinjau dari pengetahuan ibu dalam perspektif kesehatan, dengan pengetahuan yang baik bagi ibu yang memberikan ASI eksklusif bagi anak diharapkan anak bisa tumbuh dan berkembang dengan baik, memiliki daya imun/kekebalan yang cukup tinggi yang lebih lanjut akan meningkatkan status kesehatan anak. Hal tersebut penulis sampaikan karena dalam ASI ekslusif itu mengandung kolostrum, dimana kandungan kolostrum berbeda dengan air susu yang mature, karena kolostrum dan hanya sekitar 1\% dalam air susu mature, lebih banyak mengandung imunoglobin A (Iga), laktoterin dan sel-sel darah putih yang kesemuanya sangat penting untuk pertahanan tubuh bayi terhadap serangan penyakit(Infeksi), lebih sedikit mengandung lemak dan laktosa, lebih banyak mengandung vitamin dan lebih banyak mengandung mineralmineral natrium $(\mathrm{Na})$ dan seng $(\mathrm{Zn})$, sehingga bayi tampak lebih kecil dibandingkan dengan yang diberikan susu formula.

Ditinjau dari perspektif Islam, yang telah mengatur pemberian ASI tidak hanya ASI eksklusif saja, tetapi dilanjutkan sampai dengan usia 2 tahun, sesuai perintah yang ditulisan dalam Surat Al-Baqarah ayat 233 yang artinya, "Para ibu hendaklah menyusukan anak-anaknya selama dua tahun penuh, yaitu bagi yang ingin menyempurnakan penyusuan. Dan kewajiban ayah memberi makan dan pakaian kepada para ibu dengan cara ma'ruf. Seseorang tidak dibebani melainkan menurut kadar kesanggupannya. Janganlah seorang ibu menderita kesengsaraan karena anaknya dan seorang ayah karena anaknya, dan warispun berkewajiban demikian. Apabila keduanya ingin menyapih (sebelum dua tahun) dengan kerelaan keduanya dan permusyawaratan, maka tidak ada dosa atas keduanya. Dan jika kamu ingin anakmu disusukan oleh orang lain, maka tidak ada dosa bagimu apabila kamu memberikan pembayaran menurut yang patut. Bertakwalah kamu kepada Allah dan ketahuilah bahwa Allah Maha Melihat apa yang kamu kerjakan." Hikmah ayat yang terkandung dalam kitab Suci Alqur'an tersebut, setidaknya menekankan bahwa ASI sangat penting dan selayaknya bagi seorang muslim menghormati ayat-ayat Allah tersebut. Terlepas wajib atau tidaknya hukum menyusui, dalam ayat tersebut dengan tegas dianjurkan menyempurnakan masa penyusuan. Dan di sana juga disinggung tentang peran sang ayah, untuk mencukupi keperluan sandang dan pangan si ibu, agar si ibu dapat menuyusi dengan baik. Sehingga jelas, menyusui adalah kerja tim. Keputusan untuk menyapih seorang anak sebelum waktu dua tahun harus dilakukan dengan persetujuan bersama antara suami isteri dengan mengutamakan kepentingan terbaik bagi si bayi. Insprasi utama dari pengambilan keputusan ini harus didasarkan pada penghormatan kepada perintah Allah dan pelaksanaan hukum-Nya, dan tidak bertujuan meremehkan perintahNya. Demikian pula jika seorang ibu tidak bisa menyusui, dan diputuskan untuk menyusukan bayinya pada wanita lain, sehingga haknya untuk mendapat ASI tetap tertunaikan. Hasil penelitian ini menunjukan bahwa 200 responden atau $100 \%$ ibu telah melaksanakan 
perintah Allah swt. yang telah memberikan ASI kepada bayinya meskipun $16 \%$ responden memberikan secara kombinasi dengan susu formula.

\section{SIMPULAN DAN SARAN}

\section{Simpulan}

Ibu warga desa Bakulan, Cepogo, Boyolali memiliki pengetahuan tentang ASI eksklusif dengan kategori yang baik berjumlah 145 responden(72,5\%). Persentase pemberian ASI adalah 100\% responden memberikan ASI untuk bayinya. 133 responden(66,5\%) memberikan ASI ekslusif selama 6 bulan dan 35 responden(17,5\%) memberikan ASI eksklusif selama 4 bulan dan 32 responden $(16 \%)$ memberikan ASI dengan pendukung susu formula sejak usia dini.

\section{Saran}

Saran yang penulis berikan untuk institusi pendidikan, pemerintahan desa dan Puskesmas adalah perlu melakukan dan atau meningkatkan kerjasama yang bertujuan untuk meningkatkan motivasi bagi ibu mamberikan ASI eksklusif selama 6 bulan. Sedangkan saran bagi peneliti selanjutnya adalah melakukan penelitian untuk mengetahui motivasi ibu dalam memberikan ASI eksklusif dan pengaruh dari faktor-faktor yang ditemukan.

\section{DAFTAR PUSTAKA}

Anonim. 2009. Al Qur,an. Mujamma' Al Malik Fadh li Thiba'at Al Mush-haf Asy-Syarif Madinah Al Munawwarah, Kerajaan Arab Saudi.

Aprilia, Y. 2009. Analisis Sosialisasi Program Inisiasi Menyusui dan ASI Eksklusif kepada Bidan di Kabupaten Klaten. Universitas Diponegoro,Semarang

Arikunto S, 2006. Prosedur Penelitian Suatu Pendekatan Praktek. Jakarta : Rineka Cipta

Bogen, D.et.all. 2008. What do mother think about concurrant Breast Feeding and Smooking. Ambulatory Pediatric. Juornal, 8(3). Diakses tanggal 29 September 2017

Danuatmaja, B. 2007. 40 Hari Paska Persalinan. Puspa Swara,Jakarta

Depkes RI, Diit Gizi Masyarakat. 2009. Buku Panduan Manajemen Laktasi. http://gizi.depkes.go.id. Diakses tanggal 29 September 2017

Dinkes Jateng. 2011. Profil Kesehatan Jawa Tengah.

http://dinkesjatengprov.go.id. Diakses tanggal 29 September 2017 Dwiharso, CN. 2010. Tingkat Pemberian ASI Eksklusif di Indonesia Masih

Rendah. http://rri.co.id. Diakses tanggal 29 September 2017

Haniarti. 2011. Pengaruh Edukasi terhadap Perubahan Pengetahuan dan

Sikap Inisiasi Menyusui Dini dan Manajemen Laktasi pada Ibu Hamil di

Kota Parepare. Universitas Hasanudin, Makasar

Narendra, M. 2010. Tumbuh Kembang Anak dan Remaja. Sagung Seto, Jakarta 
Nursalam. 2011. Konsep dan Penerapan Metodologi Penelitian Ilmu Keperawatan Pedoman Skripsi, Tesis, dan Instrumen Penelitian Keperawatan. Salemba Medika,Jakarta

Notoatmodjo, S. 2005. Ilmu Kesehatan Masyarakat.PT. Rineka Cipta, Jakarta Partyka, B, et.all. 2010. Infant Nutrition in Saskatoon: Barrier to Infant Food Security. Canadian Journal of Dietetic. Diakses tanggal 29 September 2017

Roesli, U. 2008. Inisiasi Menyusui Dini. Pustaka Bunda, Jakarta . 2010. Inisiasi Menyusui Dini Plus ASI Eksklusif. Pustaka Bunda,Jakarta

Santosa PB., Ashari, 2005. Analisis Statistik dengan Microsoft Excel \& SPSS. Andi Offset,Yogyakarta

Sidi, P. dkk. 2010. Bahan Bacaan Manajemen Laktasi, Menuju Persalinan Aman dan Bayi Baru Lahir Sehat. Perinasia Indonesia, Jakarta

Utami, R. 2008. Mengenal ASI Eksklusif. Trubus Agriwijaya,Jakarta 
